\title{
Implementasi Sensor IMU untuk mengetahui Sudut Elevasi Kendaraan menggunakan Metode Least Square
}

\section{ERWANI MERRY SARTIKA, AUDYATI GANY, VINCENSIUS YUVENS}

\author{
Program Studi Teknik Elektro Universitas Kristen Maranatha
}

Email: erwanimerry@gmail.com

Received 30 Desember 2019 | Revised 12 Januari 2020 | Accepted 30 Maret 2020

\begin{abstract}
ABSTRAK
Kemiringan jalan menyebabkan pengendara sepeda motor lebih berhati-hati dalam mengendarai kendaraannya. Selain untuk keamanan, sudut elevasi jalan dapat mempengaruhi dalam pengendalian kendaraan sehingga dapat lebih menghemat energi. Pada paper ini sensor Inertial Measurement Unit (IMU) digunakan untuk mengetahui kemiringan kendaraan sepeda motor (naik/turun dan condong kiri/kanan). Dalam perancangannya beberapa data akselerasi dari sensor accelerometer IMU diolah dengan regresi sehingga diperoleh persamaan regresi yang kemudian digunakan untuk memperbanyak data sehingga data tersebut dapat digunakan untuk prediksi model antara 3 input nilai akselerasi dan 2 output nilai kemiringan sudut kendaraan. Prediksi model berhasil dengan indentifikasi menggunakan metode Least Square. Dari data pengamatan diperoleh bahwa ratarata kesalahan absolut untuk kemiringan naik/turun dan condong kiri/kanan antara $5^{\circ} \mathrm{s} / \mathrm{d} 7^{\circ}$, namun belum berhasil untuk sudut yang besar $\left(70^{\circ} \mathrm{s} / \mathrm{d} 90^{\circ}\right)$.
\end{abstract}

Kata kunci: IMU, accelerometer, sudut elevasi, Arduino, Least Square

\begin{abstract}
The slope of the road leads to awareness of motorcyclists ini riding their motorcycle addition to safety, the elevation angle of the road can affect vehicle control so that it can save more energy. In this paper the IMU sensor is used to determine the slope of a motorcycle (up / down and leaning left / right). In the design of some acceleration data from the IMU accelerometer sensor is processed so that the regression equation is obtained. The regression equation is used to generate the data to predict the model 3 input acceleration value and 2 output slope value of the vehicle. Model prediction was successful by identification using the Least Square method. Obtained from observational data that the average absolute error for the slope up / down and leaning left / right between $5^{\circ}$ to $7^{\circ}$, but has not been successful for wide angles ( $70^{\circ}$ to $90^{\circ}$ ).
\end{abstract}

Keywords: IMU, accelerometer, elevation angle, Arduino, Least Square 


\section{PENDAHULUAN}

Kecepatan kendaraan sepeda motor saat bergerak tentunya sangat dipengaruhi oleh kemiringan jalan. Pada saat ada tanjakan, turunan, belok ke kiri, atau belok kanan tentunya akan mempengaruhi pada pengendalian kecepatan kendaraan sepeda motor tersebut. Selain itu untuk lebih menghemat energi saat kendaraan bergerak turun, naik, belok kiri, dan belok kanan tentunya perlu dikendalikan dengan mengetahui kemiringan kendaraan sepeda motor saat bergerak. Melalui informasi sudut kemiringan juga dapat membuat pengendara sepeda motor lebih berhati-hati, karena kemiringan yang berlebih saat bergerak belok dapat menyebabkan kendaraan tersebut mengalami loss contro/(Dantes, 2013). Penambahan dan implementasi sensor Inertial Measurement Unit (IMU) pada kendaraan sepeda motor akan sangat membantu bagi pengendara untuk mengetahui posisi kendaraan yang sedang dikendarai.

Dalam sistem penentuan posisi kendaraan, sensor Inertial Measurement Unit (IMU) telah berperan penting. Akselerasi dari accelerometer IMU digunakan untuk menghitung kecepatan kendaraan, dan kemudian memperkirakan jarak kendaraan yang ditempuh ke waktu (Suwandi, dkk, 2019). Aplikasi dari sensor gyroscope dan accelerometer yang merupakan komponen penyusun alat ukur inersial (Inertial Measurement Unit) untuk mendeteksi sikap (attitude) pada wahana terbang tanpa awak (Taryana, dkk, 2015). Accelerometer adalah sebuah perangkat elektromagnetik yang berfungsi untuk mengukur akselerasi dengan tepat, percepatan karena gravitasi, mendeteksi dan mengukur getaran yang terjadi pada kendaraan, getaran pada mesin-mesin, juga getaran yang terjadi di bumi (Lee \& Jeon, 2018). Accelerometer sensitif terhadap akselerasi linier dan bidang gravitasi lokal. Percepatan linear selaras dengan arah dari sumbu yang akan memberikan output accelerometer positif. Akselerasi besarnya tergantung pada sudut kemiringan (Pedley, 2013). Estimasi orientasi menggunakan Kalman Filter digunakan untuk membantu memperkirakan gerak pada IMU (Habbachi, dkk, 2018).

Identifikasi digunakan untuk penentuan model sistem dinamis dari input/output pengukuran (Sartika, dkk, 2019). Pengetahuan tentang model diperlukan untuk desain dan implementasi sistem kontrol kinerja tinggi. Algoritma kuadrat terkecil (Least Square) menawarkan suatu profil variasi untuk keuntungan adaptasi. Dengan algoritma Least Square (kuadrat terkecil) rekursif menyebabkan semakin sedikit bobot untuk kesalahan prediksi (Landau, 2006). Identifikasi menggunakan Least Square digunakan untuk mengatasi sistem sparse, algoritma ini memanfaatkan kesalahan keluaran untuk mengontrol forgetting factor sehingga dapat meningkatkan laju konvergensi (Wang, dkk, 2015).

Board Arduino terdiri dari hardware / modul mikrokontroller dan software IDE (Integrated Development Environment). Kelebihan dari Arduino yaitu rangkaian minimum dan programmer sudah built in dalam satu board (Santoso, 2015). Sensor Fusion (Komplementer dan Kalman filter) dan filter Moving Average diimplementasikan pada Arduino mikrokontroler berbasis akuisisi data dari sensor Inertial Measurement Unit (IMU) untuk aplikasi platform yang stabil (Redhyka, dkk, 2015).

Akselerasi dari accelerometer IMU telah digunakan dalam aplikasi kendaraan. Selain itu accelerometer dapat mengukur akselerasi dengan tepat dan selaras dengan arah, sehingga dapat menentukan sudut kemiringan. Pada paper ini akan mengimplementasikan sensor IMU khususnya accelerometer untuk mengetahui sudut elevasi jalan pada kendaraan sepeda motor. Data akselerasi yang diambil dari sensor IMU berupa tiga arah $(x, y$, dan $z)$ akan digunakan untuk memperoleh dua sudut kemiringan (arah naik/turun dan arah condong ke kiri/kanan) seperti yang terjadi pada kendaraan sepeda motor akibat sudut elevasi jalan. 
Kalman Filter digunakan untuk menghasilkan data yang cukup stabil sehingga dapat membaca pergerakan kendaraan dengan lebih baik. Prediksi model dari sudut kemiringan akan dilakukan menggunakan metode Least Square. Metode Least Square dipilih karena merupakan metode yang cukup sederhana untuk memprediksi beberapa input dan output, sehingga pemrosesannya dapat dilakukan oleh pengendali Arduino. Arduino digunakan untuk membaca data sensor IMU dengan bantuan Kalman Filter dan mengeluarkan dua data sudut kemiringan yang nantinya akan digunakan untuk mengendalikan secara otomatis kecepatan dari kendaraan sehingga akan lebih efektif dan efisien.

\section{PERANCANGAN}

Perangkat yang digunakan pada penelitian ini terdiri dari sensor IMU dan Arduino. Sensor IMU digunakan untuk membaca data akselerasi dengan arah $x$, arah $y_{1}$ dan arah $z$ (selanjutnya disebut $a z, a y$, dan $a z$ ). Arduino digunakan untuk membaca dan menerima data akselerasi dari sensor IMU dan melakukan proses perhitungan hasil prediksi sudut kemiringan arah naik/turun dan condong ke kiri/kanan. Proses yang dilakukan dalam perancangan untuk menentukan sudut kemiringan ditunjukkan pada Gambar 1.

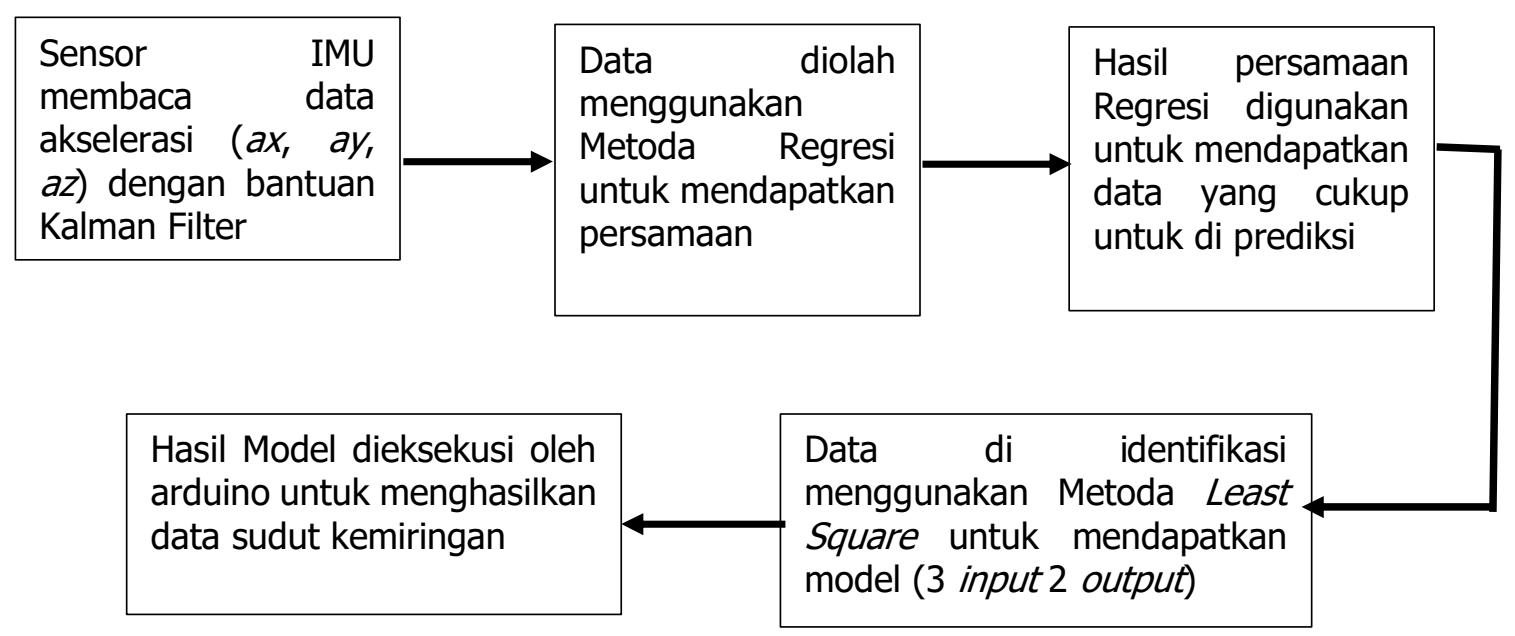

Gambar 1. Perancangan Sudut Kemiringan dari Pembacaan Akselerasi Sensor IMU

Sensor IMU membaca data akselerasi ( $a x, a y, a z)$ untuk berbagai kemiringan, namun data yang dihasilkan tidak cukup stabil. Oleh sebab itu pada proses pembacaan data akselerasi tersebut ditambahkan Kalman Filter sehingga data yang terbaca dengan baik untuk beberapa sudut kemiringan (naik /turun) dan condong (kiri/kanan). Sudut dipilih naik/turun dan condong kiri/kanan karena hasil dari perancangan ini akan digunakan untuk mengetahui sudut elevasi jalan pada kendaraan sepeda motor yang kemungkinan mengalami pergerakan tersebut.

Pengambilan data untuk posisi sensor naik/turun dengan beberapa sudut ditunjukkan pada Tabel 1. Sedangkan pengambilan data untuk posisi sensor condong ke kiri/kanan ditunjukkan pada Tabel 2. Data diambil pada beberapa sudut khusus sehingga dapat dibaca dengan tepat menggunakan busur derajat. Nilai $a x, a y$, dan $a z$ adalah nilai akselerasi pada sumbu $x$, sumbu $y$, dan sumbu $z$. 
Tabel 1. Data Posisi Sensor (Naik/Turun) terhadap Pembacaan Akselerasi ( $a x, a y$, dan az)

\begin{tabular}{|c|c|c|c|c|}
\hline $\begin{array}{c}\text { Posisi } \\
\text { Sensor }\end{array}$ & Sudut & ax & ay & az \\
\hline turun & -90 & $-250,75$ & $-0,75$ & $-7,65625$ \\
\hline turun & -60 & $-218,935$ & $-0,54839$ & 97,96774 \\
\hline turun & -45 & $-187,031$ & $-0,15625$ & 143,9688 \\
\hline turun & -30 & $-136,063$ & $-9,625$ & 187,75 \\
\hline datar & 0 & 11,12903 & 0,903226 & 232,2258 \\
\hline naik & 30 & 142,1563 & 9,4375 & 196,0313 \\
\hline naik & 45 & 198,7576 & 11,51515 & 150,9091 \\
\hline naik & 60 & 234,75 & 1,4375 & 104,6875 \\
\hline naik & 90 & 266,2258 & 8,806452 & -13 \\
\hline
\end{tabular}

Tabel 2. Data Posisi Sensor (Condong ke Kiri/Kanan) terhadap Pembacaan Akselerasi (ax, $a y$, dan $a z)$

\begin{tabular}{|c|c|c|c|c|}
\hline $\begin{array}{c}\text { Posisi } \\
\text { (condong) }\end{array}$ & Sudut & ax & ay & az \\
\hline kiri & -90 & $\mathbf{8 , 4 3 7 5}$ & $\mathbf{- 2 5 5 , 5 9 4}$ & $\mathbf{- 1 1 , 4 3 7 5}$ \\
\hline kiri & -60 & $\mathbf{- 2 3 , 9 6 7 7}$ & $\mathbf{- 2 2 1 , 2 5 8}$ & $\mathbf{1 0 3 , 5 4 8 4}$ \\
\hline kiri & -45 & $\mathbf{- 3 8 , 9 3 7 5}$ & $\mathbf{- 1 7 8 , 7 1 9}$ & $\mathbf{1 5 5 , 4 6 8 8}$ \\
\hline kiri & -30 & $\mathbf{- 5 3 , 8 4 3 8}$ & $\mathbf{- 1 2 5 , 0 3 1}$ & $\mathbf{1 9 1 , 5 6 2 5}$ \\
\hline datar & 0 & 11,12903 & 0,903226 & 232,2258 \\
\hline kanan & 30 & $-41,625$ & 133,25 & 188,625 \\
\hline kanan & 45 & $-43,6563$ & 179,2188 & 150,9375 \\
\hline kanan & 60 & $-6,35484$ & 222,1613 & 101,4194 \\
\hline kanan & 90 & 7,612903 & 255 & $-32,7742$ \\
\hline
\end{tabular}

Data yang diperoleh dari beberapa sudut kemiringan pada Tabel 1 untuk posisi kemiringan naik/turun kemudian diolah menggunakan metode regresi untuk mendapatkan persamaan dari karakteristik data tersebut (Sartika, dkk, 2019). Gambar 2 (a) adalah gambar grafik hasil regresi untuk $a x$, Gambar 2 (b) adalah gambar grafik hasil regresi untuk ay, dan Gambar 2 (c) adalah gambar grafik hasil regresi untuk $a z$. 


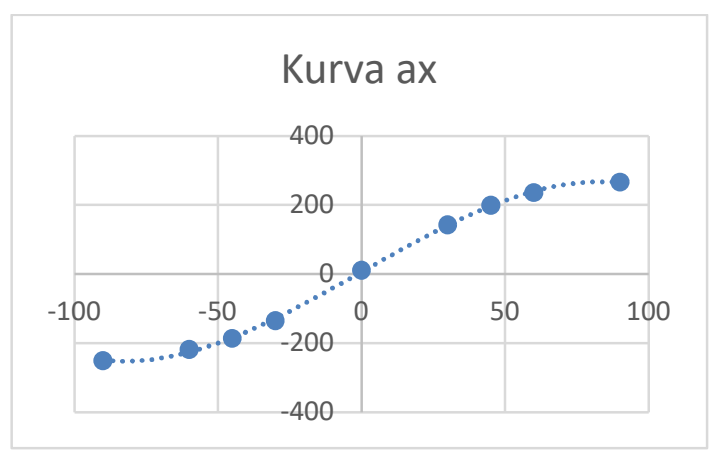

(a)

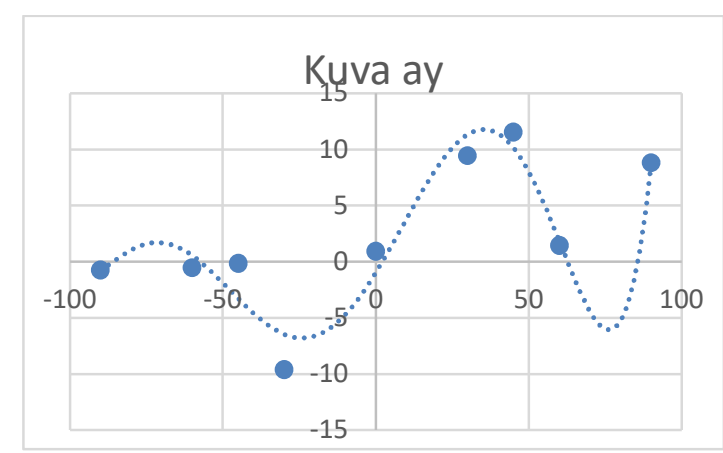

(b)

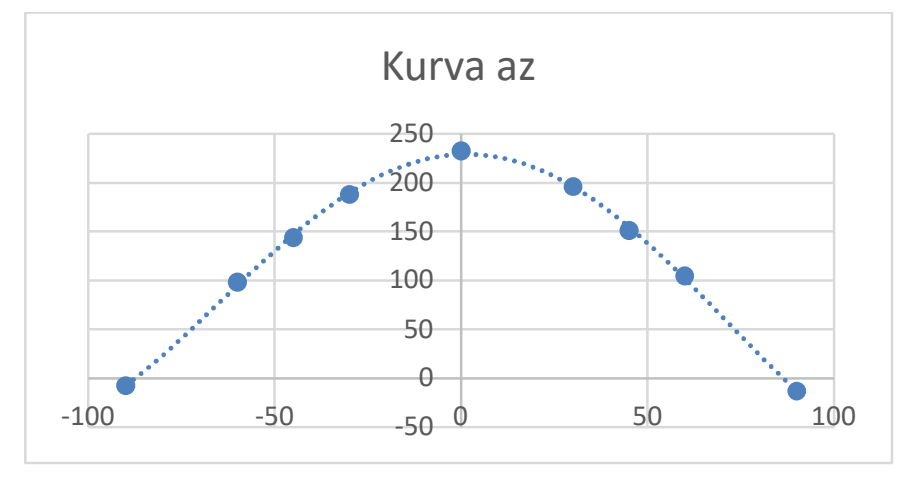

(c)

\section{Gambar 2. (a) Kurva Regresi dari Tabel 1 untuk Akselerasi Arah ax (b) Kurva Regresi dari Tabel 1 untuk Akselerasi Arah ay (c) Kurva Regresi dari Tabel 1 untuk Akselerasi Arah az}

Dari Gambar 2 diperoleh persamaan regresi untuk masing-masing arah $a x, a y$, dan azterhadap sudut kemiringan naik/turun seperti ditunjukkan pada Persamaan (1), Persamaan (2), dan Persamaan (3) dengan koefisien korelasi $\left(R^{2}\right)$.

$a_{x}=-0,0002267495 \theta^{3}+0,0002188957 \theta^{2}+4,6945092510 \theta+5,9818591166$

$R^{2}=0,9995129328$

$a_{y}=-0,0000000002 \theta^{6}+0,000000016 \theta^{5}-0,0000019172 \theta^{4}-0,0001780685 \theta^{3}+$

$0,0053652026 \theta^{2}+0,4437209315 \theta-0,9659132816$

$R^{2}=0,9127742524$

$a_{z}=0,0000014996 \theta^{4}-0,0000196405 \theta^{3}-0,0416463724 \theta^{2}+0,1286222033 \theta+$ 228,9621257005

$R^{2}=0,9991091916$

Sedangkan data yang diperoleh dari beberapa sudut kemiringan pada Tabel 2 untuk posisi kemiringan condong ke kiri/kanan kemudian diolah menggunakan metode regresi untuk mendapatkan persamaan dari karakteristik data tersebut. Gambar 3(a) adalah gambar grafik hasil regresi untuk $a x$, Gambar 3(b) adalah gambar grafik hasil regresi untuk $a y$, dan Gambar 3(c) adalah gambar grafik hasil regresi untuk $a z$. 


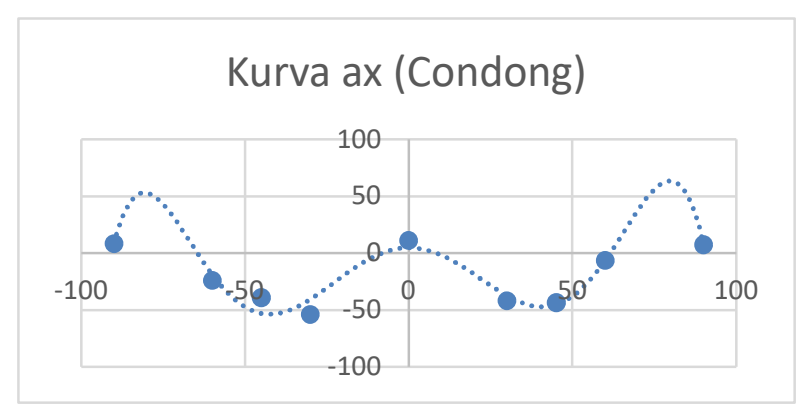

(a)

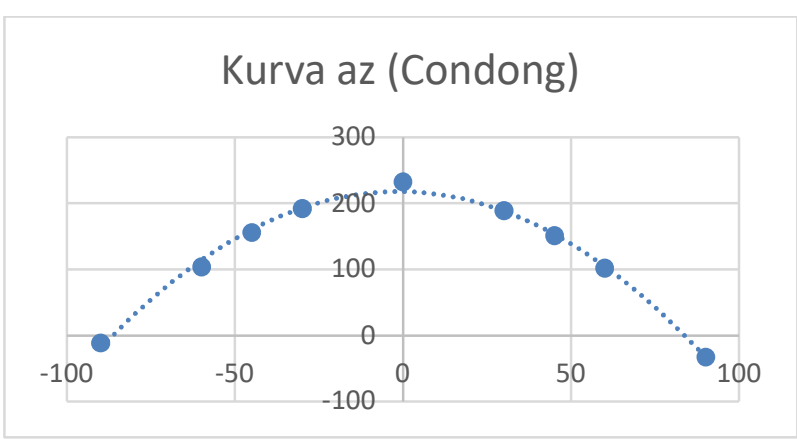

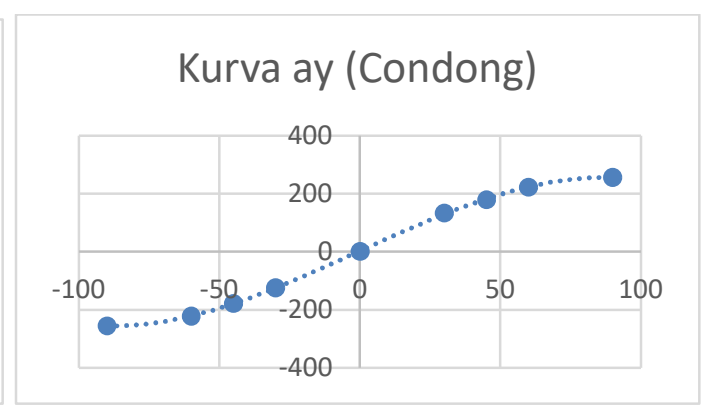

(b)

\section{(c)}

\section{Gambar 3. (a) Kurva Regresi dari Tabel 2 untuk Akselerasi Arah ax (b) Kurva Regresi dari Tabel 2 untuk Akselerasi Arah ay (c) Kurva Regresi dari Tabel 2 untuk Akselerasi Arah az}

Dari Gambar 3 diperoleh persamaan regresi untuk masing-masing arah $a x, a y$, dan azterhadap sudut kemiringan condong kiri/kanan seperti ditunjukkan pada Persamaan (4), Persamaan (5), dan Persamaan (6) dengan koefisien korelasi $\left(R^{2}\right)$.

$a_{x}=-0,0000000021 \theta^{6}-0,0000000059 \theta^{5}+0,0000255623 \theta^{4}+0,0000455638$
$-0,0698008357 \theta^{2}+0,0161510297 \theta+4,6492090155$

$R^{2}=0,9122701924$

$a_{y}=-0,0001932259 \theta^{3}-0,0003536307 \theta^{2}+4,3991612155 \theta+$ 2,2527943782

$R^{2}=0,9999044425$

$a_{z}=-0,0301286205 \theta^{2}-0,0800025848 \theta+217,8708617461$

$R^{2}=0,9936257393$

Seluruh karakteristik $a x, a y$, dan $a z$ terhadap sudut kemiringan naik/turun dan condong kiri/kanan digunakan untuk memprediksi model dari sudut kemiringan kendaraan. Seluruh persamaan kemudian digunakan untuk memperbanyak data sehingga dapat diidentifikasi modelnya dari 3 input data akselerasi menjadi 2 data output kemiringan. Identifikasi menggunakan metode Least Square digunakan untuk mendapatkan model tersebut. Metode 
Least Square memiliki gain adaptation dalam proses identifikasinya. Persamaan (7) adalah persamaan metode Least Square yang digunakan (Landau, 2006).

$$
\begin{aligned}
& \hat{y}(t+n)=-\widehat{a_{0}} y(t)+\widehat{b_{0}} u_{1}(t)+\widehat{b_{1}} u_{2}(t)+\widehat{b_{2}} u_{3}(t)=\hat{\theta}^{T} \emptyset(t) \\
& \hat{\theta}^{T}=\left[\widehat{a_{0}} \widehat{b_{0}} \widehat{b_{1}} \widehat{b_{2}}\right] \\
& \emptyset(t)^{T}=\left[-y(t) u_{1}(t) u_{2}(t) u_{3}(t)\right] \\
& e(t+1)=y(t+1)-\hat{y}(t+1) \\
& F(0)=\frac{1}{\delta} I ; 0<\delta \ll 1 \\
& F(t+1)=F(t)-\frac{F(t) \emptyset(t) \emptyset(t)^{T} F(t)}{1+\emptyset(t)^{T} F(t) \emptyset(t)} \\
& \hat{\theta}(t+1)=\hat{\theta}(t)+F(t+1) \emptyset(t) e(t+1)
\end{aligned}
$$

Keterangan :

$\hat{y}(t+1)=$ estimasi data output (sudut)

$\hat{\theta}^{T}=$ vektor parameter

$\widehat{a_{n}}$ dan $\widehat{b_{m}}=$ parameter estimasi pole dan zero

$\emptyset(t)^{T}=[-y(t), u(t)]=$ vektor pengukuran

$y(t)=$ nilai data output (sudut kemiringan naik/turun dan condong kiri/kanan)

$u(t)=$ nilai data input (ax, ay, dan az)

$e(t+1)=$ error

$y(t+1)=$ data output

$F(t)=$ gain adaptation

$I=$ matriks identitas

$F(t+1)=$ prediksi gain adaptation

$\hat{\theta}(t+1)=$ prediksi vektor parameter estimasi

Berdasarkan data yang dicari model dengan 3 data input berupa nilai accelerometer $a x, a y$, dan $a z$. Ketiga parameter accelerometer tersebut digunakan untuk memprediksi model sudut dari kendaraan dengan sensor IMU yang dipasang mendatar pada kendaraan (pada spdometer). Sudut keluaran yang digunakan adalah sudut naik atau turun dan condong ke kiri atau ke kanan. Transfer Function yang diperoleh dari hasil identifikasi dengan metode Least Square diperoleh untuk sudut kemiringan naik/turun ditunjukkan pada Persamaan (8). Sedangkan transfer function persamaan yang diperoleh dari hasil identifikasi dengan metode Least Square diperoleh untuk sudut condong ke kiri/kanan ditunjukkan pada Persamaan (9).

$$
\begin{aligned}
& \theta=\frac{0,1702}{1-0,3712 z^{-1}} a_{x}+\frac{0,0382}{1-0,3712 z^{-1}} a_{y}+\frac{0,0211}{1-0,3712^{-1}} a_{z} \\
& \theta=\frac{0,0579}{1-0,7911 z^{-1}} a_{x}-\frac{0,1812}{1-0,7911^{-1}} a_{y}+\frac{0,0274}{1-0,7911 z^{-1}} a_{z}
\end{aligned}
$$

Persamaan (8) dan (9) selanjutnya akan diuji untuk berbagai nilai akselerasi untuk mengetahui keberhasilan sudut kemiringan yang dihasilkan di bagian data pengamatan. 


\section{DATA PENGAMATAN}

Pada data pengamatan dilakukan pengambilan data berbagai nilai akselerasi untuk menguji besar sudut yang dihasilkan. Pengujian dilakukan menggunakan Simulink, dengan memasukan 3 nilai akselerasi setiap melakukan perubahan kemiringan posisi sensor IMU. Dari proses pengujian, terdapat pergeseran hasil identifikasi sehingga perlu perubahan persamaan dengan mengurangi nilai konstanta sebesar 10. Gambar 4 dan Gambar 5 adalah gambar model yang diperoleh dari metode Least Square setelah penyesuaian pergeseran. Gambar 4 adalah pengujian model menggunakan Simulink untuk sudut kemiringan naik/turun, sedangkan Gambar 5 adalah pengujian model menggunakan Simulink untuk sudut kemiringan condong ke kiri/kanan.

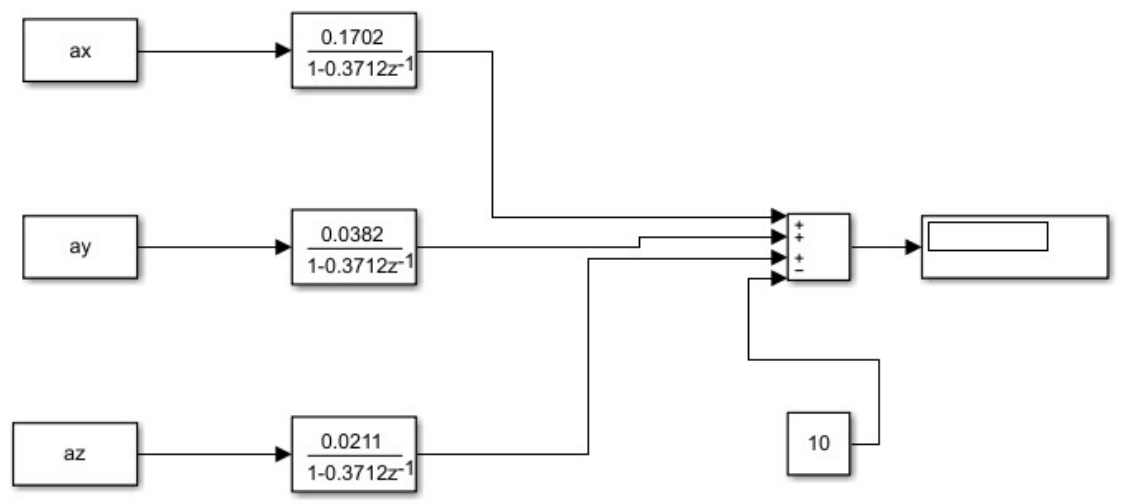

Gambar 4. Pengujian menggunakan Simulink dari Model Hasil Identifikasi Sudut Kemiringan Naik/Turun

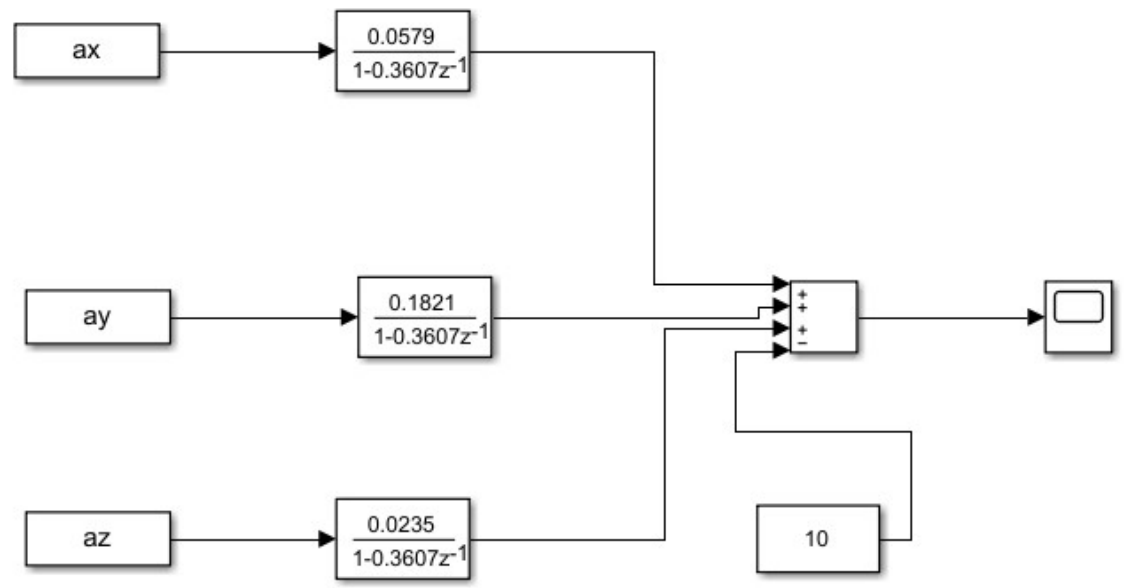

\section{Gambar 5. Pengujian menggunakan Simulink dari Model Hasil Identifikasi Sudut Kemiringan Condong Kiri/Kanan}

Tabel 3 dan Tabel 4 adalah data pengujian pengamatan data untuk pengujian prediksi model hasil identifikasi metode Least Square setelah dilakukan pergeseran dengan konstanta sebesar 10. Data diambil masing-masing 19 data untuk setiap perubahan kemiringan $10^{\circ}$ posisi sensor 
Implementasi Sensor IMU untuk mengetahui sudut Elevasi Kendaraan menggunakan Metoda Least Square

IMU. Dilakukan perhitungan kesalahan absolut dari perbedaan hasil sudut target dan sudut prediksi model.

Tabel 3. Data Pengujian Model Hasil Indentifikasi Posisi Sensor (Naik/Turun) terhadap Pembacaan Akselerasi ( $a x, a y$, dan $a z)$

\begin{tabular}{|c|c|c|c|c|c|c|c|}
\hline Uji ke- & ax & ay & az & Posisi & $\begin{array}{c}\text { Sudut } \\
\text { Target }\end{array}$ & $\begin{array}{c}\text { Sudut } \\
\text { Prediksi } \\
\text { Model }\end{array}$ & $\begin{array}{c}\text { Absolut } \\
\text { Error }\end{array}$ \\
\hline 1 & 260 & 5 & -17 & naik & 90 & 60,11 & 29,89 \\
\hline 2 & 256 & 14 & 21 & naik & 80 & 60,85 & 19,15 \\
\hline 3 & 246 & 20 & 62 & naik & 70 & 59,88 & 10,12 \\
\hline 4 & 224 & 24 & 98 & naik & 60 & 55,38 & 4,62 \\
\hline 5 & 198 & 5 & 135 & naik & 50 & 48,43 & 1,57 \\
\hline 6 & 156 & 28 & 173 & naik & 40 & 39,73 & 0,27 \\
\hline 7 & 128 & 28 & 194 & naik & 30 & 32,86 & 2,86 \\
\hline 8 & 85 & 33 & 210 & naik & 20 & 22,06 & 2,06 \\
\hline 9 & 40 & 24 & 220 & naik & 10 & 9,667 & 0,333 \\
\hline 10 & 6 & 24 & 225 & datar & 0 & 0,6322 & 0,6322 \\
\hline 11 & -45 & 26 & 221 & turun & -10 & $-13,18$ & 3,18 \\
\hline 12 & -86 & 18 & 209 & turun & -20 & $-25,17$ & 5,17 \\
\hline 13 & -134 & 26 & 187 & turun & -30 & $-38,42$ & 8,42 \\
\hline 14 & -170 & 14 & 157 & turun & -40 & $-49,9$ & 9,9 \\
\hline 15 & -196 & 15 & 126 & turun & -50 & $-57,91$ & 7,91 \\
\hline 16 & -218 & 10 & 94 & turun & -60 & $-65,25$ & 5,25 \\
\hline 17 & -240 & 10 & 52 & turun & -70 & $-72,61$ & 2,61 \\
\hline 18 & -249 & -7 & 18 & turun & -80 & $-77,22$ & 2,78 \\
\hline 19 & -253 & -3 & -23 & turun & -90 & $-79,43$ & 10,57 \\
\hline & & & & & Rata2 absolut error & 6,699747 \\
\hline & & & & & & & \\
\hline
\end{tabular}

Dari data pengamatan, rata-rata kesalahan absolut prediksi sudut sebesar $6,699747^{\circ}$ untuk kemiringan sudut naik atau turun (khususnya pada sudut yang besar $70^{\circ} \mathrm{s} / \mathrm{d} 90^{\circ}$ ) dan rata-rata kesalahan absolut prediksi sudut sebesar $5,340526^{\circ}$ untuk kemiringan sudut condong kiri atau kanan (khususnya pada sudut yang besar $70^{\circ} \mathrm{s} / \mathrm{d} 90^{\circ}$ ). Hasil identifikasi model menggunakan metode Least Square cukup mampu untuk mengenali karakteristik dari sudut kemiringan terhadap nilai akselerasi untuk sudut yang berkisar antara $0^{\circ} \mathrm{s} / \mathrm{d} 60^{\circ}$. Hal ini masih dianggap dapat mewakili keadaan sebenarnya karena kemiringan pada kendaraan sepeda motor secara nyata tidak terlalu mengalami perubahan yang sangat besar karena kendaraan dapat jatuh atau tergelincir. 
Tabel 4. Data Pengujian Model Hasil Identifikasi Posisi Sensor (Condong ke Kiri/Kanan) terhadap Pembacaan Akselerasi ( $a x, a y$, dan $a z)$

\begin{tabular}{|c|c|c|c|c|c|c|c|}
\hline Uji ke- & ax & ay & az & $\begin{array}{c}\text { Posisi } \\
\text { condong }\end{array}$ & $\begin{array}{c}\text { Sudut } \\
\text { Target }\end{array}$ & $\begin{array}{c}\text { Sudut } \\
\text { Prediksi } \\
\text { Model }\end{array}$ & $\begin{array}{c}\text { Absolut } \\
\text { Error }\end{array}$ \\
\hline 1 & 3 & 257 & -45 & kanan & 90 & 62,69 & 27,31 \\
\hline 2 & 5 & 253 & 21 & kanan & 80 & 63,13 & 16,87 \\
\hline 3 & -3 & 243 & -57 & kanan & 70 & 60,76 & 9,24 \\
\hline 4 & 26 & 216 & 104 & kanan & 60 & 57,7 & 2,3 \\
\hline 5 & 20 & 197 & 129 & kanan & 50 & 52,67 & 2,67 \\
\hline 6 & 14 & 177 & 154 & kanan & 40 & 47,35 & 7,35 \\
\hline 7 & 4 & 123 & 194 & kanan & 30 & 32,53 & 2,53 \\
\hline 8 & -1 & 86 & 208 & kanan & 20 & 22,05 & 2,05 \\
\hline 9 & -22 & 56 & 217 & kanan & 10 & 11,94 & 1,94 \\
\hline 10 & -25 & 16 & 223 & datar & 0 & 0,49 & 0,49 \\
\hline 11 & 1 & -34 & 224 & kiri & -10 & $-11,36$ & 1,36 \\
\hline 12 & 9 & -66 & 216 & kiri & -20 & $-20,04$ & 0,04 \\
\hline 13 & -5 & -114 & 198 & kiri & -30 & $-35,65$ & 5,65 \\
\hline 14 & 9 & -145 & 185 & kiri & -40 & $-43,69$ & 3,69 \\
\hline 15 & 3 & -172 & 160 & kiri & -50 & $-52,84$ & 2,84 \\
\hline 16 & -5 & -206 & 119 & kiri & -60 & $-64,76$ & 4,76 \\
\hline 17 & 5 & -233 & 76 & kiri & -70 & $-73,12$ & 3,12 \\
\hline 18 & 10 & -252 & 16 & kiri & -80 & $-80,29$ & 0,29 \\
\hline 19 & 15 & -256 & -40 & kiri & -90 & $-83,03$ & 6,97 \\
\hline & & & & & Rata2 absolut error & 5,340526 \\
\hline & & & & & &
\end{tabular}

Dari hasil pengujian, terdapat pergeseran persamaan model dari hasil identifikasi sehingga diperoleh data pengamatan yang cukup mewakili. Persamaan (10) adalah transfer function hasil akhir identifikasi dengan metode Least Square yang diperoleh untuk sudut kemiringan naik/turun. Sedangkan Persamaan (11) adalah transfer function hasil akhir identifikasi dengan metode Least Square yang diperoleh untuk sudut kemiringan condong kiri/kanan.

$$
\begin{aligned}
& \theta=\frac{0,1702}{1-0,3712 z^{-1}} a_{x}+\frac{0,0382}{1-0,3712 z^{-1}} a_{y}+\frac{0,0211}{1-0,3712 z^{-1}} a_{z}-10 \\
& \theta=\frac{0,0579}{1-0,79-1} a_{x}-\frac{0,1812}{1-0,7911 z^{-1}} a_{y}+\frac{0,0274}{1-0,7911 z^{-1}} a_{z}-10
\end{aligned}
$$

Hasil dari model tersebut kemudian dieksekusi oleh Arduino sehingga lebih praktis karena cukup sensor IMU dan Arduino dapat diletakkan pada kendaraan sepeda motor (pada spidometer) untuk menginformasikan posisi kemiringan dari sepeda motor. Dengan informasi tersebut dapat digunakan untuk langkah pengembangan selanjutnya yaitu mengendalikan kendaraan sepeda motor yang lebih efektif dan efisien. 
Implementasi Sensor IMU untuk mengetahui sudut Elevasi Kendaraan menggunakan Metoda Least Square

\section{KESIMPULAN}

Dari paper ini dapat disimpulkan bahwa sensor IMU khususnya accelerometer dapat diimplementasikan untuk mengetahui sudut elevasi kendaraan sepeda motor menggunakan metode Least Square. Melalui persamaan regresi dapat digunakan untuk menambah data sehingga dapat membantu untuk memprediksi model menggunakan metode Least Square untuk mengetahui sudut elevasi kendaraan. Model prediksi sudut elevasi kendaraan menggunakan metode Least Square berhasil diperoleh dengan kesalahan absolut antara $5^{\circ}-7^{\circ}$, namun belum berhasil untuk sudut yang besar $\left(70^{\circ} \mathrm{s} / \mathrm{d} 90^{\circ}\right)$. Untuk selanjutnya informasi sudut elevasi kendaraan yang telah diperoleh dapat diterapkan dalam pengendalian kecepatan kendaraan sepeda motor.

\section{DAFTAR RUJUKAN}

Dantes, K. R. (2013). Karakteristik Prilaku Arah Belok Kendaraan Tossa Hercules. Rekayasa Mesin. 4(2), 125-132.

Habbachi, S., Sayadi, M., Fnaiech, F., Rezzoug, N., Gorce, P., \& Benbouzid, M. (2018). Estimation of IMU Orientation Using Linear Kalman Filter based on Correntropy Criterion. IEEE International Conference on Industrial Technology (ICIT), (pp. 13401344). Retrieved from doi:10.1109/icit.2018.8352373

Landau, I. D. ;Zito G. (2006). Digital Control Systems. Design, Indentification and Implementation. Springer.

Lee, J. K., \& Jeon, T. H. (2018). IMU-based but Magnetometer-free Joint Angle Estimation of Constrained Links. IEEE SENSORS, 1-4.

Pedley, M. (2013). Tilt Sensing Using a Three-Axis Accelerometer. In Freescale Semiconductor Application Note. (pp. 1-22).

Redhyka, G. G., Setiawan, D., Soetraprawata, D., \& Design, A. M. (2015). Embedded Sensor Fusion and Moving-average Filter for Inertial Measurement Unit ( IMU ) on the Microcontroller-based Stabilized Platform. In 2015 International Conference on Automation, Cognitive Science, Optics, Micro Electro-Mechanical System, and Information Technology (ICACOMIT), (pp. 72-77).

Santoso, H. (2015). Panduan Praktis Arduino. Retrieved from www.elangsakti.com

Sartika, Erwani Merry; Sarjono, T.Rudi; Jonathan, J. (2019). Identifikasi Persamaan Plant Ball and Beam Tanpa Tuas. TESLA: Jurnal Teknik Elektro. 21(1), 62-68.

Sartika, E. M., Sarjono, R., \& Chrisophras, H. X. (2019). Sistem Pick and Place Dua Derajat Kebebasan menggunakan Metode Regresi. ELKOMIKA: Jurnal Teknik Energi Elektrik, Teknik Telekomunikasi, \& Teknik Elektronika, ス3), 521-532.

Suwandi, M. Bondan; Kitasuka, Teruaki; Aritsugi, M. (2019). Vehicle Vibration Error Compensation on IMU-accelerometer Sensor Using Adaptive Filter and Low-pass Filter 
Approaches. Journal of Information Processing, 27, 33-40. https://doi.org/10.2197/ipsjjip.27.33

Taryana, N., Nataliana, D., \& Ananda, A. R. (2015). Pendeteksi Sikap pada Model Wahana Terbang menggunakan Inertial Measurement Unit. ELKOMIKA: Jurnal Teknik Energi Elektrik, Teknik Telekomunikasi, \& Teknik Elektronika, 3(1), 16-37.

Wang, Y., Li, C., \& Tian, C. (2015). Modified Recursive Least Squares Algorithm for Sparse System Identification. 7th International Conference on Modelling, Identification and Control (ICMIC 2015), (pp. 7-11). 